\title{
Discurso do Exmo. Sr. Dr. Armando de Salles Oliveira, agradecendo o titulo de Doutor "honoris causa", que the foi conferido e aos Drs. Julio de Mesquita Filho, Christiano Altenfelder Silva e Bernardo Houssay, pela Universidade de S. Paulo.
}

"Agradeço a Universidade de S. Paulo a distinção que me confere outorgando-me o titulo de doutor "honoris causa".

Tudo aqui contribue para exaltando meu espirito, e o meu sentimento, exhaurir toda a minha capacidade de reconhecimento e de emoção.

Recebem, igualmente a investidura dois valorosos companheiros de ideal. Um, como secretario de Estado, dirigiu a fase de criação e organização do nosso grande instituto desdobrando-se em esforços para que não lhes faltassem elementos que lhe asseguraram desde os primeiros dias uma vigorosa vitalidade. $\mathrm{O}$ outro, a mim fortemente ligado mais ainda pela identidade das funções do que pelos proprios laços de familia, é o animador desinteressado de todas as obras que visem servir ao progresso moral da coletividade e não se contentando em ver realizada uma de suas antigas aspirações, continua, fóra de posição oficiais, a prestar serviços á Universidade, com nobres propositos e assidua dedicação.

Dirigindo-nos a palavra na saudação ritual falou o professor Francisco Morato eminente figura representativa da nossa inteligencia, da nossa cultura e do nosso carater; homem publico de peregrinas virtudes.

Enfim, o ilustre reitor, os professores das faculdades e os directores dos institutos, depois de tres anos de existencia da universidade e de terem conferido diploma á primeira 
turma formada pela mais joven das faculdades, reune-se nesta solenidade que implica uma reconfortante afirmação do exito e anima com novas energias a confiança dos paulistas na posição de S. Paulo, dentro da atividade espiritual e politica da nação.

Dispomos, agora, de um instrumento por meio do qual se prepararão as nossas elites dirigentes.

Daqui continuarão a sair, como no tempo em que as escolas eram independentes entre si, homens que se destinam ao exercicio da inteligencia aplicada e que constituirão sobretudo os grupos das profissões liberaes e do funcionalismo. Mas, conservando embora cada uma a sua fisionomia, as faculdades deixaram de ser corpos fragmentarios para se tornarem orgão solidarios pertencentes a um só corpo. $\mathrm{E}$ as paredes que os separam são agora permeaveis, circulando através delas o mesmo fluxo generoso do ideal universitario.

O exercicio de uma profissão nunca foi incompativel com o desinteresse e o espirito de sacrificio. A universidade fará aumentar nesse grupo os exemplares humanos que formam - segundo a expressão de Thibaubt "essa zona obscura, essa profundidade, esse substratum de espiritualidade e de inteligencias mais que desinteressadas que se encontram na raiz das elites organizadas e de que estas se afastam á medida que crescem".

\section{Conceito, moderno da Universidade}

"Marcando sua filiação ao conceito moderno da Universidade, a nossa não é apenas uma confederação de professores e estudantes mas tambem uma vasta confederação cientifica. Suas escolas e seus institutos reproduzem tanto a multiplicidade, como a unidade das ciencias que ali são ensinadas ou cultivadas.

Aqui se congregam sete grande escolas e varios institutos cientificos. Está assim a um seu objetivo mais alto - o de dar ao país homens que se votem á atividade desinte- 
ressada do espirito exercida seja na catedra, seja no laboratorio, seja pela palavra escrita.

Um dos consolidadores da nação americana compondo o proprio epitafio pediu que gravassem em seu tumulo estas palavras:

"Aqui foi enterrado Thomaz Jefferson autor da declaração da independencia americana, do Estatuto de Virginia para liberdade religiosa e fundador da Universidade da Virginia".

Deixando de aludir aos cargos eminentes que ocupára em sua esplendorosa carreira politica, aquele grande espirito - um dos maiores que apareceram no Novo Mundo julgava a criação de uma universidade um titulo de gloria tão alto como o da elaboração da carta fundamental das liberdades americanas.

Mais de um século depois de sua morte a sua influencia ainda se exerce vigorosamente nos Estados Unidos. Ha um século de distancia resoam as ultimas palavras do magnifico elogio que lhe fez outro grande americano:

"Ninguem salvo os que duvidam da existencia do sol poderá negar que com a America e na America começa uma nova éra para os negocios humanos. Esta éra é caraterizada por governos representativos livres, por sistemas aperfeiçoados de relações nacionais, por um espirito de livre exame novamente despertado e indomavel e por uma difusão de saber em toda a comunidade absolutamente sem precedentes.

A America está atada indissoluvelmente a esses grandes principios pelo destino e a despeito das vicissitudes. Se eles perecerem, nós pereceremos com ele: se eles sobreviverem será porque nós os teremos sustentado".

\section{Amparo ás elites}

"Sigamos o grande exemplo. Aos governos que se sucederem ao meu caberá o dever primeiro entre os mais altos de amparar e desenvolver a oficina em que se forjarão os 
modeladores do espirito e do coração de uma robusta nacionalidade. Da torre simbolica que se ha de erguer para a sua Reitoria, se espalhará para o Brasil uma luz inconfundivel que não sómente será um guia para os brasileiros mas ainda o ponto para onde eles se voltarão esperançados e consolados nas vicissitudes de nossa patria.

E' uma obra a ser continuada pelas gerações através de um trabalho ininterrupto, cuja cadencia dará a medida dos homens que estiverem á direção do governo. Se algum deles por um desvio da inteligencia e da visão, ilustrando mais uma vez o "pendent opera interrupta" de Virgilio cometer o crime de interromper ou desmanchar a obra que começamos nada se perderá na aparencia.

A nossa prosperidade material asegurada pela extensão e pelas riquezas das terras ainda virgens conservará certamente o seu brilho.

Nunca porém, a nossa nacionalidade poderia adquirir uma consistencia bastante forte para resistir aos ataques que desferissem contra a sua integridade. Improvisam-se soldados, mas não se improvisa a consciencia coletiva de uma nação".

\section{S. Paulo na vida nacional}

"São Paulo sabe que a influencia que exerceu e quer exercer na vida nacional sómente será legitima e duradoura se fôr inspirada pelas forças do espirito.

Por isso velará para que nunca se apaque a flama que ha tres anos aqui se acendeu. E ninguem impedirá que o mais tenue de seus raios chegue até o chão e que um dia descançará num obscuro trabalhador paulista que o destino a um tempo generoso e cruel colocou na chefia do governo de São Paulo e que hoje recebe de vossa munificiencia um premio com que nunca sonhou". 